International Journal of Social Science And Human Research

ISSN(print): 2644-0679, ISSN(online): 2644-0695

Volume 05 Issue 01 January 2022

DOI: $10.47191 / \mathrm{ijsshr} / \mathrm{v} 5-\mathrm{i} 1-42$, Impact factor-5.586

Page No: $310-314$

\title{
Competitiveness of Indonesian Mangosteen in the International Market
}

\section{Istis Baroh}

Agribusiness Department, University of Muhammadiyah Malang, Tlogomas No. 246 Street, Lowokwaru Subdistrict, Malang City, East Java, Indonesia

\begin{abstract}
The agricultural sector is the leading sector in the Indonesian economy. Mangosteen (Garcinia Mangostana Linn) or commonly called "the queen of fruits" is one of Indonesia's mainstay exotic fruits. Since the 1970s until now the demand for exports has continued to increase, so it can be said that the mangosteen fruit is the prima donna of export which is Indonesia's mainstay. The purpose of this research are to analyze the development of Indonesian mangosteen exports, the factors that affect Indonesian mangosteen exports and the competitiveness of Indonesian mangosteen in the international market in 2009-2019. This research uses secondary data form Central Bureau of Stastistics, Outlook and UN Comtrade. The development of mangosteen exports was analyzed using trend analysis; the factors that influence the development of exports were analyzed using multiple regression analysis and the competitiveness of the mangosteen in the international market was analyzed using revealed comparative advantage (RCA). The result of this research are that in $2009-2019$ the development of Indonesian mangosteen exports trends to increase; the factors of exports are real prices (negative effect), exchange rate (positive effect) and Indonesian mangosteen is competitive in the international market.
\end{abstract}

KEYWORDS: Competitiveness, Indonesian mangosteen, International market

\section{INTRODUCTION}

Indonesia is a country rich in natural resources and biodiversity. Indonesia is well known as an agricultural country because most of its population earn a living as farmers, where the agricultural sector is one of the leading sectors in its economy. Agriculturebased business will be one of promising businesses in the future, because agricultural business can increase national economic development in various broad aspects based on food crops and horticulture.

The mangosteen fruit (Garcinia mangostana Linn.) or commonly called "the queen of fruits" is a member of the Guttiferae family. This fruit plant is widely cultivated in Southeast Asian countries such as Indonesia, Malaysia, Sri Lanka, Philippines, Myanmar and Thailand. This fruit plant is one of Indonesia's mainstay fruit commodities. In Indonesia, the mangosteen plant is almost spread throughout the archipelago. Since the 1970s until now, export demand has continued to increase, so that it can be said that the mangosteen fruit is the prima donna of export which is Indonesia's mainstay (Qosim, 2013).

The need for mangosteen continues to increase along with increasing public awareness of the importance of nutrition and health. The need for the mangosteen fruit is increasing with the knowledge that the mangosteen fruit has many benefits contained in it, both in the flesh and skin of the fruit. Mangosteen fruit is widely used as traditional medicine, one of which is as a remedy for diarrhea, abdominal pain, infection and clonic ulcers. This is because mangosteen contains various substances that function as antiinflammatory, antioxidant, anti-cancer, anti-bacterial, and also have neuroprotective activity (Wulan, 2015).

Mangosteen is widely marketed in the form of fresh fruit, currently there are 29 districts that are listed as producers and contributors of mangosteen fruit for export and to fulfill domestic needs, which include: Tasikmalaya, Sawahluno/Sijunjung, Tapanuli, Purwakarta, Subang, Bogor, Lahat, City of Agam, Tabenan, Fifty Cities, Pasaman, Sukabumi, Pontianak, Blitar, Banyuangi, Purwokerto, Kampar, Kerinci, Merangin, West Lombok, Tanggarbus, Lebong, Trenggalek, Bangai Islands, Mamasa, Dompu, Paso and Banggai (Syarfuddin, 2009).

Table 1. Mangosteen Production in Indonesia in 2009-2019

\begin{tabular}{|l|l|}
\hline Year & Amount of Mangosteen Production (Tons)Year \\
\hline 2009 & 105.558 \\
\hline 2010 & 84.538 \\
\hline 2011 & 117.595 \\
\hline
\end{tabular}




\begin{tabular}{|l|l|}
\hline 2012 & 190.287 \\
\hline 2013 & 139.602 \\
\hline 2014 & 114.755 \\
\hline 2015 & 203.100 \\
\hline 2016 & 162.862 \\
\hline 2017 & 161.751 \\
\hline 2018 & 228.148 \\
\hline 2019 & 246.476 \\
\hline
\end{tabular}

Source: Processed from the Directorate General of Horticulture and Statistics Indonesia (2019).

Table 1 shows that the production of mangosteen fluctuates, but in general it has increased. How many mangosteens are marketed abroad and how is Indonesia's mangosteen competitive ability in the international market is background of this research. The purpose of this research are to analyze the development of Indonesian mangosteen exports, the factors that affect Indonesian mangosteen exports and the competitiveness of Indonesian mangosteen in the international market in 2009-2019. The title of this research is "COMPETITIVENESS OF INDONESIAN MANGGIS IN THE INTERNATIONAL MARKET".

\section{Term Limit}

This term limitation is made with the aim that there is a common perception between the writer and the reader.

The term limits include:

1. Competitiveness is the ability to compete among mangosteen exporting countries in the international market.

2. Mangosteen fruit is a fruit that can be consumed directly or further processed into food and beverage products. Indonesian mangosteen is mangosteen produced by farmers in Indonesia.

3. The data used is secondary data in 2009-2019.

4. The amount of local mangosteen production is the amount of mangosteen produced by farmers from mangosteen cultivation at the local mangosteen farm level (on-farm) in tons/year.

5. The number of exported mangosteen fruit is the number of mangosteen fruit sold outside Indonesia in tons/year.

6. Domestic market is all trading activities that take place in a country other than export and import.

7. The international market is the world market. International trade is a relationship of economic activity between countries which is realized by the process of exchanging goods and services on a voluntary and mutually beneficial basis.

\section{RESEARCH METHODS}

\section{Data Types and Sources}

The type of data used in this research is secondary data. Secondary data is data obtained not directly from the source, but obtained from related agencies and from other sources. In this study obtained from the Central Statistics Agency (BPS), the Indonesian Ministry of Trade, literature studies and other information.

\section{Methods and Data Analysis}

This study uses descriptive and quantitative data analysis methods. Data analysis method to analyze the development of mangosteen fruit exports using trend analysis. Mathematically the linear trend method is written as follows:

$\hat{\mathrm{Y}} \mathrm{t}=\mathrm{a}+\mathrm{b} 1 . \mathrm{t}$

Description

$\hat{\mathrm{Y}} \mathrm{t} \quad=$ forecast for the future period after period $\mathrm{t}$

A $\quad$ intercept

B = slope increase or decrease

Factors influencing export development were analyzed using multiple regression analysis. Mathematically the equation is as follows:

$\mathrm{Y}=\mathrm{a}+\mathrm{b} 1 \mathrm{X} 1+\mathrm{b} 2 \mathrm{X} 2+\mathrm{b} 3 \mathrm{X} 3+\mathrm{ei}$

Where:

$\mathrm{Y} \quad=$ Amount of Indonesian mangosteen fruit exported (tonnes)

$\mathrm{X} \quad=$ Price of Indonesian mangosteen (Rp)

$\mathrm{X} 2=$ Indonesian mangosteen fruit production (tonnes)

A $\quad=$ constanta

$\mathrm{b} 1 ; \mathrm{b} 2=$ Regression coefficient

The competitiveness of mangosteen in the international market was analyzed using Revealed Comparative Advantage (RCA). Mathematically written as follows:

$$
R C A=\frac{X i / X j}{X i j / X w}
$$




\section{Competitiveness of Indonesian Mangosteen in The International Market}

Description:

$\mathrm{Xij} \quad=$ Export value of commodity $\mathrm{i}$ from country $\mathrm{j}$

$\mathrm{Xj} \quad=$ The total value of the country's exports

Xiw $=$ Export value of commodity $\mathrm{i}$ from the world

$\mathrm{Xw} \quad=$ Total world export value

\section{RESULTS AND DISCUSSION}

\section{A. Indonesian Mangosteen Export Development}

Indonesia is the fifth largest mangosteen producing country in the world. This is because Indonesia has natural potential that greatly supports the growth and development of the mangosteen plant as a tropical fruit crop. On the other hand, the world's demand for mangosteen continues to increase so that the world's demand for mangosteen also increases. In general, the volume and value of Indonesia's mangosteen exports increased, in detail presented in table 2.

Table 2. Mangosteen Export Volume in Indonesia in 2009-2019

\begin{tabular}{lll}
\hline Year & Mangosteen Export Volume (Tons) & Mangosteen Export Value (USD) \\
\hline 2009 & 11.31 & 11.319 \\
2010 & 11.38 & 11.388 \\
2011 & 12.60 & 12.603 \\
2012 & 20.16 & 20.169 \\
2013 & 7.648 & 5.734 \\
2014 & 10.08 & 6.545 \\
2015 & 38.17 & 17.212 \\
2016 & 34.95 & 20.220 \\
2017 & 9.167 & 4.031 \\
2018 & 38.83 & 33.268 \\
2019 & 27,79 & 42.630 \\
\hline
\end{tabular}

Source: Processed from (Agricultural Data and Information System Center, 2019)

Indonesian mangosteen export volume since 2009 - 2019 has fluctuated with an increasing trend. The years $2009-2012$ experienced an increase, especially in 2011-2012 an increase of 60\% but had decreased by 62\% and then increased again until 2017. The export value of Indonesian mangosteen fluctuated in line with its export volume in 2009 - 2012, decreased in 2013 and 2014, increased again in 2015-2016 while in 2017 it fell again due to the decline in the rupiah exchange rate against the US dollar. In 2018 the rate of development of the mangosteen export value was high at 725.25\% (Center for Agricultural Data and Information Systems, 2019)

Graphically the development of export volume can be described as follows:

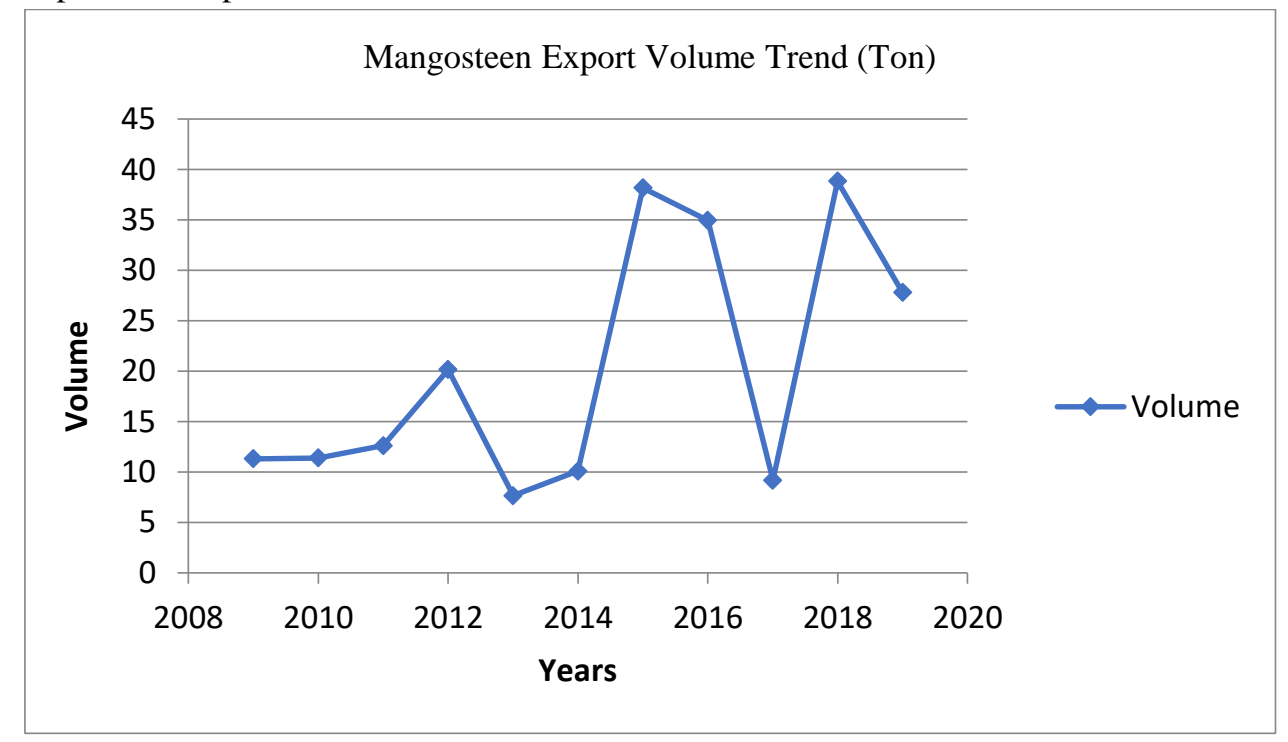

Figure 1. Development of Indonesian Mangosteen Export Volume in International Market 


\section{Competitiveness of Indonesian Mangosteen in The International Market}

In figure 1 it can be seen that the export volume of Indonesian mangosteen fluctuates every year. The amount of value a is 20,189 tons, meaning that the export volume of Indonesian mangosteen without the influence of time is 20,189 tons. The amount of coefficient (b) of the time period against the export volume of Indonesian mangosteen is $2.2(b=2.2)$, meaning that the increase of 1 year then the volume of Indonesian mangosteen exports will increase by 2.2 tons and the magnitude of the coefficient of determination of the export volume trend line (R2) 0.3454 .

The average development of Indonesian mangosteen export volume is $97 \%$ percent per year with a trend that tends to increase. The increase in Indonesian mangosteen exports is supported by domestic production which tends to continue to increase over time. The contribution of Indonesian mangosteen export volume to the world market in 2001 amounted to 1.1 percent of the world's mangosteen exports and increased in 2015 by 2.35 percent of the total world mangosteen exports (Reni K et al, 2019)

\section{B. Factors Affecting the Development of Indonesia's Mangosteen Export Volume for 11 years (2009-2019)}

Based on the results of multiple regression analysis, the results obtained are that domestic prices have a negative effect; exchange rate has a positive effect and production has a positive effect.

Coeficient

\begin{tabular}{|c|c|c|c|c|c|c|}
\hline \multirow[b]{2}{*}{ Model } & & \multicolumn{2}{|c|}{ Unstandardized Coefficients } & \multirow{2}{*}{$\begin{array}{l}\text { Standardized } \\
\text { Coefficients } \\
\text { Beta }\end{array}$} & \multirow[b]{2}{*}{$\mathrm{t}$} & \multirow[b]{2}{*}{ Sig. } \\
\hline & & B & Std. Error & & & \\
\hline \multirow[t]{4}{*}{1} & (Constant) & -56.278 & 19.122 & & -2.943 & .026 \\
\hline & Real price & -.006 & .002 & -1.404 & -2.698 & .036 \\
\hline & $\begin{array}{l}\text { Exchange } \\
\text { rate }\end{array}$ & .007 & .003 & 1.221 & 2.786 & .032 \\
\hline & Production & .262 & .074 & 1.009 & 3.525 & .012 \\
\hline
\end{tabular}

The results of the regression analysis showed that the variables that influenced the volume of Indonesian mangosteen exports were the mangosteen price (-1.404) with 3.6\%; the rupiah exchange rate against the US dollar (1.221) with 3.2\%; and mangosteen production in Indonesia (1.009) with $1.2 \%$. The effect of the price of mangosteen $(-1.404)$ with $3.6 \%$, meaning that if the price of mangosteen is increased by $1 \%$, the volume of Indonesian mangosteen exports will decrease by $1.404 \%$ and vice versa if the price of mangosteen is decreased by $1 \%$, the volume of Indonesian mangosteen exports will increase by $1.404 \%$ at the level of $96 \%$ confidence. This is in accordance with the law of demand that price is inversely proportional to demand.

The effect of the rupiah exchange rate on the US dollar (1.221) with 3.2\%, meaning that if the rupiah exchange rate against the US dollar increases by $1 \%$, the volume of Indonesian mangosteen exports will increase by $1.221 \%$ and vice versa if the rupiah exchange rate against the US dollar decreases $1 \%$, the volume of mangosteen exports Indonesia will decrease by $1.221 \%$ at the $96 \%$ confidence level. This was due to the increase in the rupiah exchange rate against the US dollar motivating producers (in this case Indonesia) to increase their export volume because it would increase their profits and vice versa. The decline in the rupiah exchange rate against the US dollar will also reduce the profits of exporters.

The effect of mangosteen production (1.009) with 1.2\%, meaning that if mangosteen production in Indonesia increases by $1 \%$, the volume of Indonesian mangosteen exports will increase by $1.009 \%$ and vice versa if mangosteen production in Indonesia decreases by $1 \%$, the volume of Indonesian mangosteen exports will decrease by $1.009 \%$ at the $98 \%$ confidence level. This is natural because ideally all products are sold out so as not to lose because agricultural products do not last long.

\section{Competitiveness of Indonesian Mangosteen in the International Market}

One tool to measure the competitiveness or comparative advantage of a commodity among fruit commodities in Indonesia (in the case of Indonesian mangosteen) is the Revealed Comparative Advantage (RCA) index. The RCA index of a commodity is obtained by comparing the export value of that commodity to the export value of the world's agricultural commodities. In this study 5 commodity fruits consisting of mangoes, bananas, oranges, pineapples, avocados in Indonesia in 2009 - 2019.

From the results of RCA calculations on 5 commodities of these fruits over a period of 11 years (2009 - 2019) experienced fluctuations. Fluctuations in the RCA index of 5 commodity fruits are presented in table 3.

Table 3. Indonesia Mangosteen RCA Index Value 2009-2019

\begin{tabular}{|l|l|}
\hline Tahun & RCA \\
\hline 2009 & 0,83 \\
\hline 2010 & 1,06 \\
\hline 2011 & 0,89 \\
\hline 2012 & 2,21 \\
\hline
\end{tabular}




\begin{tabular}{|l|l|}
\hline 2013 & 2,05 \\
\hline 2014 & 3,14 \\
\hline 2015 & 4,24 \\
\hline 2016 & 3,70 \\
\hline 2017 & 4,14 \\
\hline 2018 & 0,64 \\
\hline 2019 & 1,07 \\
\hline
\end{tabular}

Source: FAO UN, 2018-2019. Statistics Indonesia (BPS), 2013-2017

\section{CONCLUSIONS}

Based on the results of research and discussion can be concluded that:

1. The development of Indonesian mangosteen export volume in 2009-2019 fluctuates every year and tends to increase.

2. The development of Indonesian mangosteen export volume in the international market is influenced by the price of mangosteen (negative influence), rupiah exchange rate against the US dollar and Indonesian mangosteen production (positive influence).

3. Mangosteen Indonesia is competitive in the international market.

\section{RECOMMENDATIONS}

It is recommended that Indonesia to develop mangosteen cultivation techniques so that the continuity of production is maintained, and improve the quality of mangosteen products.

\section{REFERENCES}

1) Statistics Indonesia. (2017). Indonesia's Annual Fruit and Vegetable Crop Statistics 2017 (Vol. 7, Issue 2, p. 109). http://www.bps.go.id

2) Statistics Indonesia. (2013). Statistics of Fruits and Vegetables. http://www.bps.go.id

3) Statistics Indonesia. (2015). Fruit and Vegetable Crop Statistics Annual Indonesia. http://www.bps.go.id

4) Statistics Indonesia. (2016). Fruit and Vegetable Crop Statistics Annual Indonesia. http://www.bps.go.id

5) Ministry of Agriculture Republic Indonesia, P.D. and S. I. P. (2019). Outlook for Mangosteen Horticultural Agricultural Commodities. In Jakarta.

6) Kustiari, R., Purba, H. J., \& Hermanto. (2016). Analysis of The Competitiveness of Indonesian Mangosteen in the World Market (Case Study in West Sumatra). Journal of Agro-Economics, 30(1), 81. https://doi.org/10.21082/jae.v30n1.2012.81107

7) Nations, F. and A. O. of the U. (2019). Major Tropical Fruits Statistical Compendium. In Statistical Compendium Rome FAO.

8) Qosim, W. A. (2013). Development of Mangosteen Fruit as An Export Commodity of Indonesia. Cultivation Journal, 12(1), 40-45. http://pustaka.unpad.ac.id/wp- content/uploads/2014/02/Jurnal-Kultivasi_Manggis.pdf

9) United Nations, F. and A. O. (2018). Major Tropical Fruits Statistical Compendium. In Rome. https://doi.org/10.4060/ca5688en

10) Wulan, A. J. (2015). Mangosteen Fruit (Garcinia mangostana L.) as An Alternative Memory Protector Mangosteen fruits (Garcinia mangostana L.) as Memory Protector. 58-63. 